\title{
Anti-Reissner's fibre and anti-p73 co-expression in the subcommissural organ of the mice and rats with spontaneous hydrocephalus
}

\author{
Agustín Castañeyra-Perdomo*1,2, Ibrahim González-Marrero 1,2, \\ Paloma Fernández-Rodriguez ${ }^{1}$, Teresa A Ruiz-Mayor ${ }^{2}$, Leandro Castañeyra- \\ Ruiz¹, Juan M González-Toledo², Agustín Castañeyra-Ruiz¹, Lidia Ruiz- \\ Mayor $^{2}$ and Emilia M Carmona-Calero ${ }^{1,2}$
}

\author{
Address: ${ }^{1}$ Departamento de Biotecnología, Instituto de Investigación y Ciencias de Puerto del Rosario, Fuerteventura, Spain and ${ }^{2}$ Departamento \\ de Anatomía, Facultad de Medicina, Universidad de La Laguna, Tenerife, Islas Canarias, Spain \\ Email: Agustín Castañeyra-Perdomo* - acastane@ull.es \\ * Corresponding author
}

from $\left.5\right|^{\text {st }}$ Annual Meeting of the Society for Research into Hydrocephalus and Spina Bifida Heidelberg, Germany. 27-30 June 2007

Published: 20 December 2007

Cerebrospinal Fluid Research 2007, 4(Suppl I):S24 doi:10.1 I86/1743-8454-4-SI-S24

This abstract is available from: http://www.cerebrospinalfluidresearch.com/content/4/SI/S24

C 2007 Castañeyra-Perdomo et al; licensee BioMed Central Ltd.

\section{Background}

Reissner's fibre (RF) is formed by the polymerisation of the glycoprotein secreted by the subcommissural organ (SCO). The SCO also secretes soluble glycoprotein into the cerebrospinal fluid (CSF), variations in the RF and SCO have been reported in hydrocephalus. The protein p73 belongs to the tumor suppressor factor family, which also includes $\mathrm{p} 53$ and $\mathrm{p} 63$. The p73 has several isoforms: the transactivating (TA) isoform that induces apoptosis through p53 target genes and the $\mathrm{N}$-terminal truncated $(\Delta \mathrm{N})$ isoform whose levels are dramatically decreased when there is sympathetic neuron apoptosis. Thereafter, p73 isoform equilibrium is involved in neuronal survival and death. In the present work, we analyze the variations of RF and p73 co-expression in the CSF and SCO of the spontaneously hydrocephalus mouse and rat.

\section{Materials and methods}

Brains from mice and rats with spontaneous hydrocephalus of 5 and 12 months of age respectively were used. Control mice and control rats (CoR) of the same ages were also used. The paraffin section containing the SCO was immunohistochemically processed with anti-TAp73, anti- $\triangle$ Np73 anti-Reissner fibre (AFRU). p73 and AFRU band were also detected in the CSF by western blot.

\section{Results}

The different parts of the subcommissural organ ependymal and hypendymal cells showed AFRU immunoreactive material (ir) which was altered in the mice and rats with spontaneous hydrocephalus. The anti-TAp73 was present in the apical part of the SCO ependymal cells, while the hypendymal cell did not show Tap73-ir, the hydrocephalic animals also showed Tap73-ir but with an important variation in its expression when compared with the control. However, the $\Delta \mathrm{Np} 73$ was expressed in the cellular nucleus but was scarcely present in the SCO of both rat and mouse groups. The choroideus plexus and other brain structures showed both the isoforms of p73 immunoreactive material with some differences when the mouse and rat groups were compared. This result could mean that the glycoprotein of Reissner's fibre and the Tap73 are interconnected in the functions of the SCO in this kind of animal, which produce alterations in the subcommissural organ secretions. Protein bands were found in the CSF of the hydrocephalic rats that were scarcely 
present or almost undetectable in the CSF of the control rats.

\section{Conclusion}

Hydrocephalus produces alterations in the secretions of the SCO of the mouse and rat and Tap73 protein could play a role in the normal function of the SCO, since TAp73 is interconnected with glycoprotein secreted by the SCO. The alteration of this interconnection produces changes in the secretions of the circumventricular structures and consequently variations of some of the proteins in the CSF.

Publish with Bio Med Central and every scientist can read your work free of charge

"BioMed Central will be the most significant development for disseminating the results of biomedical research in our lifetime. " Sir Paul Nurse, Cancer Research UK

Your research papers will be:

- available free of charge to the entire biomedical community

- peer reviewed and published immediately upon acceptance

- cited in PubMed and archived on PubMed Central

- yours - you keep the copyright

Submit your manuscript here:

http://www.biomedcentral.com/info/publishing_adv.asp 